\title{
Primary versus delayed primary skin closure for prevention of surgical site infections in contaminated abdominal surgery: A meta-analysis of randomized controlled trials.
}

Almegdad Sharafaldin Mohamed Ahmed ( $D$ Almegdadsharaf@gmail.com )

Faculty of medicine-University of Khartoum https://orcid.org/0000-0002-3814-9922

Ali mohammed ali mohammed ahmed

Faculty of medicine - University of Khartoum https://orcid.org/0000-0003-2438-5673

Basil Abubakr Yagoub Ibrahim

Faculty of medicine - University of Khartoum https://orcid.org/0000-0002-8691-5900

Mohammed.a.adam

Faculty of medicine - University of Khartoum

Ali Yasen Y. Mohamedahmed

Sandwell and West Birmingham Hospitals NHS trust, United Kingdom, MSc (Human Anatomy), MRCS (Edinburgh), MD

Omer El.Faroug H.Salim

Associate professor Faculty of Medicine - University of Khartoum, Soba Teaching Hospital, Khartoum, Sudan, FRCS, MD

Systematic Review

Keywords: surgical site infection, primary skin closure, delayed primary skin closure, wound infection

Posted Date: May 7th, 2021

DOI: https://doi.org/10.21203/rs.3.rs-503306/v1

License: (ㅇ (i) This work is licensed under a Creative Commons Attribution 4.0 International License. Read Full License 


\title{
Abstract
}

Background and purpose of the study: Surgical site infections (SSIs) are one of the most common hospital acquired infections. Delayed primary skin closure (DPC) is a technique that can be used when there is a contaminated or dirty wound. The purpose of this study was to evaluate the effectiveness of DPC in reducing SSIs in dirty and contaminated abdominal surgeries compared to primary skin closure (PC).

Methods: An electronic search was conducted using six databases and clinical trials registers, only randomized controlled trials (RCTs) were included. selection of the included studies and data extraction were conducted by more than one reviewer independently. All of the included studies were assessed for the risk of bias. Pooling of the data was performed for surgical site infections as a primary outcome, and the length of hospital stay.

Main findings:12 RCTs were included in the final analysis, including 1456 patients that were randomized to receive either PC or DPC. Complicated appendicitis was the most common type of wounds with a percentage of (82.8\%). Pooling of the data showed a significant difference between the two methods, and DPC was found effective in reducing the risk for SSI with a risk ratio of $0.56([95 \% \mathrm{Cl}: 0.44,0.72], \mathrm{P}<0.001)$. The length of hospital stay was slightly lower in the PC group with a mean difference of $0.25(95 \% \mathrm{Cl}: 0.02,0.48)$ days from DPC group.

Conclusions: DPC might be more effective than PC in reducing the risk of SSIs, however most of the studies included in this meta-analysis conveyed a high risk of bias, hence more well-designed RCTs are recommended in this area.

\section{Introduction}

Surgical site infection (SSI) is a common problem following abdominal surgery, and is one of the most common causes of nosocomial infections, especially in dirty surgical wounds[1-3]. It is estimated that up to $45 \%$ of surgical patients develop SSIs [4]. SSI confer unpleasant effects on patients including: pain, increased costs of treatment and length of hospital stay $[3,5,6]$. In addition, it also has also been linked with increased morbidity and mortality, increased expenditure of health resources, repeated surgery, and other post-operative complications such as scar formation, surgical sepsis, wound dehiscence and increased risk for incisional hernia.[1-3, 5, 7, 8].

Several methods have been developed to compact SSIs, one of these methods is Delayed primary skin closure (DPC), a wound closure method which has been developed in world war I [3,9]. DPC is a technique that can be used when there is a contaminated or dirty wound allowing the wound to be drained, by leaving the wound for 5-6 days - usually-instead of closing it immediately which is what is happening in primary wound closure (PC), hence preventing the accumulation of microorganism within the wound, it requires no specialist equipment and it is also suitable for developing world practices[2, 10]. It also increases blood supply and oxygenation to the surgical site [11, 12]. Despite these benefits, DPC has downsides resulted from the need for routine dressings, these includes increased costs of treatments, and pain $[13,14]$.

Numerous studies compared the efficacy of DPC and PC in reducing the risk for SSI. However, there has been a controversy in evidence of the superiority of one method over the other, some studies suggested that DPC is superior, other found no difference between the two methods, and one even found that PC is superior to DPC in decreasing the risk for SSIs [15-17]. Additionally, two previously conducted meta-analyses showed controversy in results, one suggesting that DPC is superior, while the other stating that there was no evidence suggesting such claim, however, they both agreed on the fact that the included studies conveyed many methodological flaws, and there is a need for large scale and well-designed randomized controlled trials (RCTs). The aim of this study was to accumulate the updated evidence about this topic and compare DPC against PC to assess its effectiveness in reducing SSI of contaminated abdominal wounds.

\section{Methods And Materials}

\author{
Data Sources and Search Strategy
}

A systematic online search has been conducted using the following databases and clinical trial registers: PubMed, Scopus, the Cochrane Database of Systematic Reviews (CENTRAL), clinical trials.gov, ScienceDirect, and VHL (virtual health library). No publication dates or language restriction has been applied to the search. The search has been performed by three independent reviewers. And it was performed using the following keywords: Abdomen, surgery, Enterostomy, Appendicitis, Prevention \& Control, Adverse Effects, Complications, Wounds and injuries, Surgical wound infection, abdominal surgery, wound healing, Surgical wound dehiscence, Surgical wound infection (s), RCTs, delayed primary closure, DPC, Laparotomy, randomized controlled trial, Controlled clinical trial, Random allocation. Mesh terms and different domain operators have been used. manual search of reference lists in relevant previous systematic reviews and RCTs has been undertaken to identify randomized trials of potential interest. Last search has been conducted on March 2021.

Studies selection process

After completion of databases and clinical registers search, titles and abstracts of the identified studies have screened by two authors independently to identify the potentially eligible studies. After that the full-text of these potentially eligible articles have been screened independently by two authors to decide which articles to be included or excluded based on specified inclusion criteria which are: RCTs that compared PC and DPC of the skin layer of contaminated and dirty abdominal surgical incisions have been included. Delayed primary wound closure has been defined as the planned action to leave the skin edges unopposed (following fascial closure) with a delayed attempt to subsequently oppose the skin edges. Any surgical incision and 
operation of the abdomen have been included in the study. Additionally, exclusion criteria for studies were: Non-randomized studies, studies where the fascia was left open, and studies considering planned healing by secondary intention (where no assessment for delayed closure was planned) have been excluded from this review. Any disagreement between the authors on inclusion and exclusion decisions has been resolved via discussion and consensus.

\section{Data Extraction}

More than one reviewer has extracted the data independently, any discrepancies in outcome extraction have been resolved by re-examination until consensus has been achieved. Data extraction has been on study design, included randomization technique, intervention arms, wound contamination as defined by the criteria set by the Centers for Disease Control and Prevention [18], wound management before delayed closure, concomitant antibiotic therapy, time to first assessment for delayed closure, method of delayed closure, the definition of wound infection, and method of assessment for wound infection. Details relating to included patients were: number, age, sex, operation indication, and presence of comorbidities.

\section{Outcome Measures}

The primary outcome that has been assessed for meta-analysis is the rate of SSI, as defined by the individual study. Secondary outcome recorded was the length of hospital stay.

\section{Assessment of Bias}

Risk of bias has been assessed using the Cochrane Collaboration tool for assessing the risk of bias in randomized trials [19]. This tool covers 6 domains: selection bias, performance bias, detection bias, attrition bias, reporting bias, and other bias. Each domain will be scored as a high, low, or unclear risk of bias. Since blinding of the operating surgeon will not be possible, this has not been assessed as a source of high bias. To counter this, adequate randomization has been considered vital to minimize the risk of bias introduced by lack of blinding. Blinding of the outcome assessor has been considered feasible and its absence, a source of high bias. Studies with poor, uncertain, or unclear methods of randomization have been considered to be at high risk of bias.

\section{Statistical Analysis}

The risk ratios (RRs) have been used as the statistical measure for dichotomous outcomes. The RRs have been calculated from the original data and meta-analysis has been performed using the Mantel-Haenszel method. The RRs represents the risks of an adverse event (SSI) occurring in the experimental group (DPC) vs the control group (PC). $\mathrm{P}<.05$ has been considered significant for all analyses, $95 \%$ confidence interval was used in this study. Moreover, for pooling of the data of hospital stay, mean difference (in days) between DPC and PC groups have been used. Furthermore, betweenstudy heterogeneity has been assessed using the $\mathrm{I} 2$ and X 2 statistic and funnel plots. Higher values of $\mathrm{I} 2$ and the $\chi 2$ statistic will signify increasing levels of heterogeneity, with $\mathrm{P}<.05$ or an 12 value exceeding $50 \%$ indicating significant heterogeneity [20]. when significant heterogeneity was reported, random-effects model has been used for all endpoints, in addition to that a fixed-effects model has been used [21]. Statistical analyses have been performed using Review Manager 5.0 (Nordic Cochrane Centre, Cochrane Collaboration).

\section{Results}

\section{Studies characteristics}

Search results yielded a total of 2799 study, of them 2774 were excluded via title and abstrct screening for being either duplicates or non-revlevant to the topic of the review. 25 studies were included in the full text-screening, 12 exluded for being dupplicates and 1 study was exluded because it was not a RCT [22], leaving 12 studies to be included in the final meta-anlysis. Figure 1 demenostrates the PRISMA flow chart and the studies selection process. patients numbers were diversed among the studies, with a total of 1456 patients radmoized to recive either PC (753 patients) or DPC (703 patients), Table 1 shows charachertistics of included studies. Gender distribution was considered in all studeis,with a majority of 829 (57\%) patients as males, while 627 (43\%) of them were females. Regarding difference in age groups, two studies include pediatics patients only [17, 23], and four studies include adults only[ $[7,15,24,25]$, while the rest of the studies included both pediatrics and adults patients[1, 5, 16, 26-28].

Clincal diagnoses, appendicities was diagnosed in seven studies [15-17, 23, 24, 26, 27], appendicities plus other clinical conditions was the diagnosis in three studies[1], [5],[7]. peritonitis was in only one study [28], and in other study the diagnosis was ulcerative colitis [25]. Surgeries were done correspondingly with clinical diagnosis, appendectomy was done in eight studies[5, 15-17, 23, 24, 26, 27],two studies performed laparotomy [7],[16], and one study did reverse closer of ileostomy [25]. Regarding surgical incisions, right lower quadrant muscle splitting (McBurney's point) was done in four studies [5, 23, 24, 27], three studies performed midline incision [5, 25, 28],other three studies did Grid Iron incision [15, 16, 26], and two studies used para-median incision [5, 26]. On the other hand, the type of incision used wasn't mentioned in 3 studies [1, 7, 17]. Regadiding patients follow-up period, it wasn't mentioned in two studies $[16,28]$, other than that the duraiton varied among the studies ranging from 5 days up to 5 weeks post-operativelly.

Risk of bias assessment of the included stuides revealed that most of the studies had a high risk of bias, Fig. 2, illustrates risk of biass assement rsults of the included studies. The most common source of bias was allocation concelment. Chatwiriyacharoen et al study showed the highest rsik of bias comared to other studies [17], in some studies the risk of bias wasn't clear to be assessed[26, 28]. 
Qualitative analysis:

Regarding surgical prophylaxis, in six studies the patients were given the antibiotics pre and post operatively $[15-17,23,24,26]$, whereas three studies reported giving antibiotics preoperatively only [7, 25, 27]. In one study the antibiotics were given postoperatively only [5], and in two studies there was no mention of antibiotics administration [1,28].Types of antibiotics administrated were not specified in most of the studies, however five studies mentioned the types, which are demonstrated in Table 2. The duration of antibiotics administration after the operation was specified only in three studies, with Chatwiriyacharoen et al stating a duration of 5-10 days postoperative [17], while in Duttaroy et al study antibiotics where administered for 7 days postoperative [5], and Patients in third study where given antibiotics till discharge from the hospital [16].

Interventions done on the DPC patients varied across the studies, both in the context of type and frequency. In four studies [5, 15, 23, 24], the wound was left open and dressed with saline-soaked gauze, whereas Chatwiriyacharoen et al and Chiang et al used betadine soaked-gauze for wound dressing[17, 27]. In one study [26], the surgeons inserted the sutures to the wound but the edges were left open, and dry absorbent dressing was used. Other three studies[7, 16, 28] did not specify the type of dressing nor the specific intervention. In yet another two studies[1, 25], the wounds were left open and packed with saline soaked gauze without dressing. Regarding the frequency of dressing, the daily change of dressings was the method used in six studies [15-17, 23, 27, 28]. In one study[28], the dressings were changed twice daily, where as in another study [5], the wounds were dressed only once for the $48 \mathrm{hrs}$. after surgery. There is no data available regarding the frequency in the remaining four studies.

Regarding Differences in the definition of SSI among the studies, two studies defined SSI as the presence of gross purulent discharge with or without positive bacterial culture $[23,27]$. Another three studies said that any purulent discharge from the wound requiring drainage or repeated dressings is considered as SSI [17, 25, 26], but one of them also added having surrounding cellulitis as an alternative criterion for the definition of SSI.[17], in other four studies they have used the CDC criteria of diagnosing SSI's in their trials, the CDC criteria can be concluded by saying "the presence foul-smelling purulent discharge from the incision with or without laboratory confirmation and with or without local inflammatory or systemic signs (fever, tachycardia)" $[1,5,7,24]$. The remaining three studies didn't mention a definition of SSI $[15,16,28]$.

The Time of the first evaluation of DPC had some variation between the studies. In one study they started to evaluate the wound immediately the first day after the surgery [7]. Another study started on day 2 postoperatively[5]. three studies started to evaluate the wound on the 3rd postoperative day[1, $25,28]$. two studies started their wound evaluation on day 3 to the 5 th and day 3 to the 7th-day, respectively $[16,24]$. In another study, they started on day 4 , and in another, they started on day 5 respectively $[23,27]$. three studies didn't mention when they have started the first wound evaluation $[15,17$, 26].

The most commonly isolated bacterial pathogens are E. coli, pseudomonas aeruginosa, Bacteroides, klebsiella, staphylococci and streptococci. In 4 studies [5, 24, 26, 27], E. coli represented approximately $50 \%$ of the isolates, and it accounted for $72.8 \%$ of the isolates in another study [17]. additionally, Pettigrew et al reported that Bacteroides fragilis accounts for $46 \%$ of the isolates from SSI. Hospital charges and treatment costs were mentioned by two studies, Cohn et al study reported no significant difference between the two groups, among DPC patients they were $\$ 22,258$ [range $\$ 10,001-\$ 47,927$ ] and $\$ 26,352$ [range $\$ 5,127-\$ 45,822]$ among PC patients, while Siribumrunwong et al study stated that the costs of treatment were significantly higher among DPC with a median of with a median difference of -2083 Baht (approximately 60 US\$)[1,24].

Quantitiative analysis

Surgical site infections

12 studies compared surgical site infections between primary closure group and delayed primary closure group and were included in the analysis [1, 5 , $27,28,7,15-17,23-26]$. Using a fixed-effects model the results favored the DPC group with a risk ratio of 0.56 [95\% Cl:0.44, 0.72$]$, as the risk of SSIs between PC and DPC groups, and the difference between the groups was statistically significant ( $p$ value $<0.001)$ Fig. 3 . However, the heterogeneity among the studies was high (Heterogeneity: $\left.\mathrm{Chi}^{2}=47.66, \mathrm{df}=11(\mathrm{P}<0.00001) ; \mathrm{I}^{2}=77 \%\right)$, to identify the potential sources of heterogeneity different factors were explored including the age groups of the included patients, usage of surgical prophylaxis, and studies that has high weight, though none of these factors were recognized as a source of heterogeneity. Because of the high heterogeneity, random-effects model was used, yielding a risk ratio of 0.59 [95\% Cl:0.32, 1.08] favoring DPC group, however the difference between the group was not significant $(p$ value $=0.09)$ Fig. 4 .

Subgroup analysis was conducted for appendectomy surgeries, in which 7 studies were included, the risk ratios favoring delayed primary closure group were 0.70 [95\% Cl:0.51, 0.95], and 0.75 [95\% Cl:0.32, 1.78] using fixed and random effects models, respectively. This difference was significant when using a fixed-effects model $(p$ value $=0.02)$, however it wasn't when random-effects was used $(p$ value $=0.52)$ Figs. 5,6 .

Length of hospital stay

Regarding the length of hospital stay (LOS), 7 studies have compared it between primary closure group and delayed primary closure were included in the analysis[1, 16, 23-25, 27, 28]. pooling of data using a fixed-effects model revealed that the length of hospital stay was slightly lower in the primary closure group with a mean difference of $0.25[95 \% \mathrm{Cl}: 0.02,0.48]$ days from delayed primary closure group, additionally, this difference between the two groups was statistically significant $(p$ value $=0.03$ ) Fig. 7. pooling the data from the 7 studies demonstrated high heterogeneity among the studies (Heterogeneity: $\left.\mathrm{Chi}^{2}=184.95, \mathrm{df}=6(\mathrm{P}<0.00001) ; \mathrm{I}^{2}=97 \%\right)$, the source of heterogeneity was not identified, so a random-effects model was used in 
which the length of hospital stay was also lower in primary closure group compared to delayed primary closure group with a mean difference of 0.81 $[95 \% \mathrm{Cl}:-0.76,2.38]$ days, however this time the difference was not statistically significant ( $p$ value = 0.31) Fig. 8.

\section{Discussion}

This meta-analysis explored the efficacy of DPC versus PC, using the frequency SSIs as a main point of comparison. DPC came to notice during world war I, and became the standard measure of closure of contaminated and dirty wounds during world II [9, 29]. Several studies evaluated the efficacy of DPC and PC after that, however there were a controversy in their findings. In this study, 12 randomized controlled trials were included, and the final analysis revealed that patients in the DPC group has a lower risk ratio of acquiring SSIs than PC group and the difference between the groups was statistically significant when using the fixed - effect model. This finding was in contrast to a previously conducted meta-analyses in them there were no significant association between the two groups of comparison[3, 14]. However, it was in consistency with Bhangu et al and Tang et al studies [2, 30]

The length of hospital stay was lower in the PC group compared to the DPC group, however the difference between the groups was slight. Similar results were also reported in three previous studies, and similarly the difference between the two groups was considered of low clinical significance, because of the fact that its more reasonable to aim at reducing the rate of SSI rather than to focus on reducing the length of hospital stay and risk the SSI and it's complications [2,3,30]. This longer hospital stay in the DPC group may be attributed to the waiting time required for evaluation and dressings before wound closure. Although this time was considered of low clinical significance, it may increase health related costs in DPC compared with PC and hence decreasing the cost-effectiveness of this method. When using the random-effect model, the statistical difference between the PC and the DPC groups was not significant in both SSI and LOS, and this may be explained by the fact that the random-effect model tends to underestimate the overall effect, and thus the P-value may not reach a statistically significant value.

The costs of hospital treatment were mentioned only by two studies, no difference between PC and DPC was found in one of them, while the other reported higher costs for DPC [1,24]. This may be due to the increased equipment needed for DPC and the longer hospital stay. Although this might give a clue that PC is more cost-effective method than PC, detailed cost-effectiveness studies ought to be conducted before drawing such a conclusion.

The heterogeneity among the include studies in this review were found to be high, and the source of this heterogeneity was unidentifiable, the same was also reported in previous meta-analyses [2,3]. Although in most of the included studies appendectomies were the performed surgeries, other types of surgeries were performed in some studies, this may be a source of heterogeneity. In addition to that the included studies included different age groups, and the definition of SSI varies among the studies.

Using antibiotics prophylaxis as method of decreasing the risk for SSIs has been a standard for care for many years, numerous studies and guidelines emphasized the importance of surgical antibiotic prophylaxis (SAP) [31-35]. In this review the usage of SAP varied tremendously among the included studies, some studies used them preoperatively, others postoperatively, while others used it pre- and post-operatively. Additionally, diversity of antibiotics types that were used in the studies, and administration duration also differed form study to study. This difference may be due to the different guidelines adopted by different hospitals, and the different rates of compliance to these guidelines among the surgeons. This difference might be also a contributor to the heterogeneity among the results of the included studies.

Interventions used on DPC patients also diverged among the studies, ranging from dressing the wound with saline-soaked, betadine-soaked and dry absorbent dressings. Frequency of dressing also varied among studies ranging from twice daily, once daily, and once only after the surgery. This might have contributed to the difference in SSIs rates reported in DPC groups in the included studies and a cause of heterogeneity in this review.

DPC is known for decreasing wound contamination by anaerobes, however it provides an access for aerobic bacteria like Staphylococci to contaminate the wounds [26,36]. Despite the use of different methods of wound dressing, type of surgeries, antibiotic prophylaxis among the included studies, E-coli was the most commonly isolated organism. Although Staphylococcus aureus is considered the most common cause of SSIs, E-coli is a commonly isolated organism with an emergence of resistant strains [37].

A strength of this study that it included only RCTs, however it also had limitations including the high level of heterogeneity reported which might be due to the inclusion of RCTs of different types operations, methods of intervention, definitions of SSIs, patients age groups, and matching criteria of the included patients. Additionally, most of the included studies had a high risk of bias especially detection and selection biases. More large size RCTs, with a uniform method of intervention and SSI definition are ought to be conducted.

\section{Conclusion}

This final meta-analysis revealed that Delayed primary skin closure of contaminated and dirty wounds in abdominal surgeries might be more effective than primary closure in reducing the risk of SSIs. However, most of the studies included in this meta-analysis conveyed a high risk of bias, hence more well-designed RCTs are recommended in this area. 


\section{Declarations}

\section{Declarations}

** Sources of financial support: none.

** Declaration of conflict(s) of interest: none.

\section{Acknowledgement}

The authors would like to thank Dr. Mohammed Elshiekh for his technical support.

\section{References}

1. Cohn SM, Giannotti G, Ong AW, Varela JE, Shatz D V, mckenney MG, et al. Prospective randomized trial of two wound management strategies for dirty abdominal wounds. Ann Surg [Internet]. 2001;233(3 CC-Colorectal Cancer CC-Injuries CC-Wounds):409-413. Available from: https://www.cochranelibrary.com/central/doi/10.1002/central/CN-00328162/full

2. Bhangu A, Singh P, Lundy J, Bowley DM. Systemic review and meta-analysis of randomized clinical trials comparing primary vs delayed primary skin closure in contaminated and dirty abdominal incisions. JAMA Surg. 2013;

3. Siribumrungwong B, Noorit P, Wilasrusmee C, Thakkinstian A. A systematic review and meta-analysis of randomised controlled trials of delayed primary wound closure in contaminated abdominal wounds. World Journal of Emergency Surgery. 2014.

4. Anthony T, Murray BW, Sum-Ping JT, Lenkovsky F, Vornik VD, Parker BJ, et al. Evaluating an evidence-based bundle for preventing surgical site infection: A randomized trial. Arch Surg. 2011;

5. Duttaroy DD, Jitendra J, Duttaroy B, Bansal U, Dhameja P, Patel G, et al. Management strategy for dirty abdominal incisions: primary or delayed primary closure? A randomized trial. Surg Infect (Larchmt) [Internet]. 2009;10(2 CC-Colorectal Cancer CC-Upper GI and Pancreatic Diseases CCWounds):129-136. Available from: https://www.cochranelibrary.com/central/doi/10.1002/central/CN-00720577/full

6. Kusachi S, Kashimura N, Konishi T, Shimizu J, Kusunoki M, Oka M, et al. Length of stay and cost for surgical site infection after abdominal and cardiac surgery in Japanese hospitals: Multi-center surveillance. Surg Infect (Larchmt). 2012;

7. Lozano-Balderas G, Ruiz-Velasco-Santacruz A, Díaz-Elizondo JA, Gómez-Navarro JA, Flores-Villalba E. Surgical Site Infection Rate Drops to 0\% Using a Vacuum-Assisted Closure in Contaminated/Dirty Infected Laparotomy Wounds. Am Surg [Internet]. 2017;83(5 CC-Wounds):512-514. Available from: https://www.cochranelibrary.com/central/doi/10.1002/central/CN-01410396/full

8. Grace RH, Cox SJ. Dehiscence of Anastomoses and Wounds: Incidence of Incisional Hernia following Dehiscence of the Abdominal Wound. J R Soc Med [Internet]. 1973;66(11):1091-2. Available from: https://doi.org/10.1177/003591577306601114

9. Hepburn HH. Delayed primary suture of wounds. British medical journal. 1919 Feb 15;1(3033):181.

10. Russell GG, Henderson R, Arnett G. Primary or delayed closure for open tibial fractures. The Journal of bone and joint surgery. British volume. 1990 Jan;72(1):125-8.

11. Fogdestam I, Niinikoski J. Delayed primary closure. Tissue gas tensions in healing rat skin incisions. Scandinavian journal of plastic and reconstructive surgery. 1981 Jan 1;15(1):9-14.

12. Fogdestam I, Jensen FT, Nilsson SK. Delayed primary closure. Blood-flow in healing rat skin incisions. Scandinavian journal of plastic and reconstructive surgery. 1981 Jan 1;15(2):81 - 5.

13. Burnweit C, Bilik R, Shandling B. Primary closure of contaminated wounds in perforated appendicitis. Journal of pediatric surgery. 1991 Dec 1;26(12):1362-5.

14. Henry MC, Moss RL. Primary versus delayed wound closure in complicated appendicitis: an international systematic review and meta-analysis. Pediatric surgery international. 2005 Aug 1;21(8):625 - 30.

15. Ahmad M, Ali K, Latif H, Naz S, Said K. ORIGINAL ARTICLE COMPARISON OF PRIMARY WOUND CLOSURE WITH DELAYED PRIMARY CLOSURE IN PERFORATED APPENDICITIS. 2014;26(2).

16. Khan Kl, Mahmood S, Akmal M, Waqas A. Original Article Comparison of rate of surgical wound infection, length of hospital stay and patient convenience in complicated appendicitis between primary closure and delayed primary closure. 2009;596-8.

17. Chatwiriyacharoen W. Surgical wound infection post surgery in perforated appendicitis in children. Journal of the Medical Association of Thailand = Chotmaihet Thangphaet. 2002 May 1;85(5):572-6.

18. B'erard F. Postoperative wound infections: the influence of ultraviolet irradiation of the operating room and of various other factors. Ann Surg. 1964;160(1):1-92.

19. Higgins JP, Altman DG, Gøtzsche PC, Jüni P, Moher D, Oxman AD, Savović J, Schulz KF, Weeks L, Sterne JA. The Cochrane Collaboration's tool for assessing risk of bias in randomised trials. Bmj. 2011 Oct 18;343.

20. Lau J, loannidis JP, Schmid CH. Quantitative synthesis in systematic reviews. Annals of internal medicine. 1997 Nov 1;127(9):820-6.

21. Dersimonian R, Laird N. Meta-analysis in clinical trials. Control Clin Trials. 1986;7(3):177-88.

Page $6 / 12$ 
22. Brown SE, Allen HH, Robins RN. The use of delayed primary wound closure in preventing wound infections. American journal of obstetrics and gynecology. 1977 Apr 1;127(7):713-7.

23. Tsang TM, Tam PK, Saing H. Delayed primary wound closure using skin tapes for advanced appendicitis in children: a prospective, controlled study. Archives of Surgery. 1992 Apr 1;127(4):451-3.

24. Siribumrungwong B, Chantip A, Noorit P, Wilasrusmee C, Ungpinitpong W, Chotiya P, Leerapan B, Woratanarat P, McEvoy M, Attia J, Thakkinstian A. Comparison of superficial surgical site infection between delayed primary versus primary wound closure in complicated appendicitis: a randomized controlled trial. Annals of surgery. 2018 Apr;267(4):631.

25. Lahat G, Tulchinsky H, Goldman G, Klauzner JM, Rabau M. Wound infection after ileostomy closure: a prospective randomized study comparing primary vs. delayed primary closure techniques. Techniques in coloproctology. 2005 Dec 1;9(3):206-8.

26. Petticrew RA. Delayed primary wound closure in gangrenous and perforated appendicitis. 1981;68:635-8.

27. Chiang RA, Chen SL, Tsai YC. Delayed primary closure versus primary closure for wound management in perforated appendicitis: a prospective randomized controlled trial. J Chin Med Assoc [Internet]. 2012;75(4 CC-Wounds):156-159. Available from:

https://www.cochranelibrary.com/central/doi/10.1002/central/CN-00830461/full

28. Nasib g, shah si, bashir ea. Original article laparotomy for peritonitis: primary or delayed primary closure ? 2015;27(3):543-5.

29. Coller FA, Valk WL. The delayed closure of contaminated woundS: A preliminary report. Annals of surgery. 1940 Aug;112(2):256.

30. Tang S, Hu W, Hu L, Zhou J. Primary versus delayed primary incision closure in contaminated abdominal surgery: a meta-analysis. Journal of Surgical Research. 2019 Jul 1;239:22-30.

31. Burke JF. The effective period of preventive antibiotic action in experimental incisions and dermal lesions. Surgery. 1961 Jul 1;50(1):161-8.

32. Vaisbrud V, Raveh D, Schlesinger Y, Yinnon AM. Surveillance of antimicrobial prophylaxis for surgical procedures. Infection Control \& Hospital Epidemiology. 1999 Sep;20(9):610-3.

33. Gyssens IC, Geerligs IEJ, Dony JMJ, Van Der Vliet JA, Van Kampen A, Van Den Broek PJ, et al. Optimising antimicrobial drug use in surgery: An intervention study in a Dutch university hospital. J Antimicrob Chemother. 1996;

34. Hampson G. Prophylactic antibiotics in surgery. J Int Med Sci Acad. 2013;26(4):207.

35. Bratzler DW, Dellinger EP, Olsen KM, Perl TM, Auwaerter PG, Bolon MK, Fish DN, Napolitano LM, Sawyer RG, Slain D, Steinberg JP. Clinical practice guidelines for antimicrobial prophylaxis in surgery. Surgical infections. 2013 Feb 1;14(1):73-156.

36. Stone HH, Hester Jr TR. Topical antibiotic and delayed primary closure in the management of contaminated surgical incisions. Journal of Surgical Research. 1972 Feb 1;12(2):70 - 6;

37. Barie PS, Eachempati SR. Surgical site infections. Surg Clin North Am. 2005;85(6):1115-35.

\section{Tables}


Table 1

characteristics of the included studies.

\begin{tabular}{|c|c|c|c|c|c|c|c|c|}
\hline Study & $\begin{array}{l}\text { Country } \\
\text { of the } \\
\text { study }\end{array}$ & $\begin{array}{l}\text { Age } \\
\text { group }\end{array}$ & $\begin{array}{l}\text { Number of } \\
\text { participants } \\
\text { Total } \\
\text { (male/female) }\end{array}$ & $\begin{array}{l}\text { Number of } \\
\text { patients in } \\
\text { interventions } \\
\text { groups: } \\
\text { PC: } \\
\text { (male/female) }\end{array}$ & $\begin{array}{l}\text { Type of surgical } \\
\text { procedure (s) } \\
\text { In the study }\end{array}$ & $\begin{array}{l}\text { Antibiotic } \\
\text { prophylaxis }\end{array}$ & $\begin{array}{l}\text { Intervention } \\
\text { (s) performed }\end{array}$ & $\begin{array}{l}\text { Follow-up } \\
\text { period }\end{array}$ \\
\hline & & & & $\begin{array}{l}\text { DPC: } \\
\text { (male/female) }\end{array}$ & & & & \\
\hline $\begin{array}{l}\text { Pettiqrew } 1981 \\
\text { [26] }\end{array}$ & $\begin{array}{l}\text { New } \\
\text { Zealand }\end{array}$ & $\begin{array}{l}\text { Adults } \\
\text { and } \\
\text { children }\end{array}$ & $122(68 / 54)$ & $\begin{array}{l}\text { PC: } 80 \\
(49 / 31) \\
\text { DPC: } 42 \\
(19 / 23)\end{array}$ & Appendectomy & Yes & $\begin{array}{l}\text { monofilament } \\
\text { nylon sutures } \\
\text { were inserted } \\
\text { with the } \\
\text { edges left } \\
\text { open; gauze } \\
\text { dressing } \\
\text { covered by a } \\
\text { dry absorbent } \\
\text { dressing was } \\
\text { used }\end{array}$ & 4 weeks \\
\hline Tsang 1992 [23] & $\begin{array}{l}\text { United } \\
\text { Kingdom }\end{array}$ & Pediatrics & $63(34 / 29)$ & $\begin{array}{l}\text { PC: } 38 \\
(21 / 17) \\
\text { DPC: } 25 \\
(13 / 12)\end{array}$ & Appendectomy & Yes & $\begin{array}{l}\text { Skin and } \\
\text { subcutaneous } \\
\text { tissue were } \\
\text { left open with } \\
\text { saline } \\
\text { dressing }\end{array}$ & 33 days \\
\hline Cohn 2001 [1] & USA & $\begin{array}{l}\text { Adults } \\
\text { and } \\
\text { children }\end{array}$ & $49(37 / 12)$ & $\begin{array}{l}\text { PC: } 23(21 / 2) \\
\text { DPC: } 26 \\
(16 / 10)\end{array}$ & Not-specified & $\begin{array}{l}\text { Not- } \\
\text { specified }\end{array}$ & $\begin{array}{l}\text { wounds were } \\
\text { packed with } \\
\text { saline-soaked } \\
\text { gauze }\end{array}$ & 5 weeks \\
\hline $\begin{array}{l}\text { Chatwiriyacharoen } \\
2002 \text { [17] }\end{array}$ & Thailand & pediatrics & $44(20 / 24)$ & $\begin{array}{l}\text { PC: } 22 \text { (Not } \\
\text { specified) } \\
\text { DPC: } 22 \text { (Not- } \\
\text { specified) }\end{array}$ & $\begin{array}{l}\text { Surgery for } \\
\text { perforated } \\
\text { appendix }\end{array}$ & Yes & $\begin{array}{l}\text { the wound } \\
\text { was dressed } \\
\text { daily and } \\
\text { packed with } \\
\text { Betadine } \\
\text { gauze }\end{array}$ & 5-14 days \\
\hline Lahat 2005 [25] & Palestine & Adults & $40(19 / 21)$ & $\begin{array}{l}\text { PC: } 20(8 / 12) \\
\text { DPC: } 20 \\
(11 / 9)\end{array}$ & $\begin{array}{l}\text { Reversal } \\
\text { (closure) of } \\
\text { ileostomy }\end{array}$ & Yes & $\begin{array}{l}\text { The wound } \\
\text { was left open } \\
\text { and packed } \\
\text { with saline } \\
\text { soaked gauze }\end{array}$ & $\begin{array}{l}\text { Up to } 2 \\
\text { weeks } \\
\text { post- } \\
\text { operatively }\end{array}$ \\
\hline Duttaroy 2009 [5] & India & $\begin{array}{l}\text { Adults } \\
\text { and } \\
\text { children }\end{array}$ & $77(68 / 9)$ & $\begin{array}{l}\text { PC: } 40(37 / 3) \\
\text { DPC: } 37 \\
(31 / 6)\end{array}$ & $\begin{array}{l}\text { (Appendectomy, } \\
\text { Resection and } \\
\text { anastomosis, } \\
\text { Repair of } \\
\text { perforations, } \\
\text { abscess } \\
\text { drainage) }\end{array}$ & Yes & $\begin{array}{l}\text { the wound } \\
\text { packed with } \\
\text { saline-soaked } \\
\text { gauzes, which } \\
\text { were kept for } \\
48 \mathrm{~h} \text { without } \\
\text { any } \\
\text { manipulation. } \\
\text { The dressing } \\
\text { was done for } \\
\text { the first time } \\
48 \mathrm{~h}\end{array}$ & 5 weeks \\
\hline Chiang 2012 [27] & Taiwan & $\begin{array}{l}\text { Adults } \\
\text { and } \\
\text { children }\end{array}$ & $70(41 / 29)$ & $\begin{array}{l}\text { PC: } 36 \\
(21 / 15) \\
\text { DPC: } 34 \\
(20 / 14)\end{array}$ & Appendectomy & Yes & $\begin{array}{l}\text { The wound } \\
\text { was packed } \\
\text { with diluted } \\
\text { Betadine } \\
(0.5 \% \\
\text { povidone } \\
\text { iodine)- } \\
\text { soaked gauze } \\
\text { that was } \\
\text { changed daily }\end{array}$ & $\begin{array}{l}\text { At least } 2 \\
\text { weeks } \\
\text { post- } \\
\text { operatively }\end{array}$ \\
\hline Khan 2012 [16] & Pakistan & $\begin{array}{l}\text { Adults } \\
\text { and } \\
\text { children }\end{array}$ & $100(69 / 31)$ & $\begin{array}{l}\text { PC: } 50 \\
(27 / 23) \\
\text { DPC: } 50 \\
(42 / 8)\end{array}$ & Appendectomy & Yes & $\begin{array}{l}\text { The wound } \\
\text { was left open } \\
\text { and daily } \\
\text { dressing was } \\
\text { performed }\end{array}$ & $\begin{array}{l}\text { Not- } \\
\text { specified }\end{array}$ \\
\hline
\end{tabular}




\begin{tabular}{|c|c|c|c|c|c|c|c|c|}
\hline Study & $\begin{array}{l}\text { Country } \\
\text { of the } \\
\text { study }\end{array}$ & $\begin{array}{l}\text { Age } \\
\text { group }\end{array}$ & $\begin{array}{l}\text { Number of } \\
\text { participants } \\
\text { Total } \\
\text { (male/female) }\end{array}$ & $\begin{array}{l}\text { Number of } \\
\text { patients in } \\
\text { interventions } \\
\text { groups: } \\
\text { PC: } \\
\text { (male/female) }\end{array}$ & $\begin{array}{l}\text { Type of surgical } \\
\text { procedure (s) } \\
\text { In the study }\end{array}$ & $\begin{array}{l}\text { Antibiotic } \\
\text { prophylaxis }\end{array}$ & $\begin{array}{l}\text { Intervention } \\
\text { (s) performed }\end{array}$ & $\begin{array}{l}\text { Follow-up } \\
\text { period }\end{array}$ \\
\hline & & & & $\begin{array}{l}\text { DPC: } \\
\text { (male/female) }\end{array}$ & & & & \\
\hline Ahmad 2014 [15] & Pakistan & Adults & $158(56 / 102)$ & $\begin{array}{l}\text { PC: } 79 \\
(26 / 53) \\
\text { DPC: } 79 \\
(30 / 49)\end{array}$ & Appendectomy & Yes & $\begin{array}{l}\text { the wound } \\
\text { was left open, } \\
\text { dressing daily } \\
\text { with saline } \\
\text { soaked gauze }\end{array}$ & $\begin{array}{l}8 \text { days } \\
\text { post- } \\
\text { operatively }\end{array}$ \\
\hline Nasib 2015 [28] & Pakistan & $\begin{array}{l}\text { Adults } \\
\text { and } \\
\text { children }\end{array}$ & $70(57 / 13)$ & $\begin{array}{l}\text { PC: } 35(27 / 8) \\
\text { DPC: } 35 \\
(30 / 5)\end{array}$ & Laparotomy & $\begin{array}{l}\text { Not- } \\
\text { specified }\end{array}$ & $\begin{array}{l}\text { The wound } \\
\text { was left open } \\
\text { and dressing } \\
\text { was } \\
\text { performed as } \\
\text { needed }\end{array}$ & $\begin{array}{l}\text { On a } \\
\text { weekly } \\
\text { basis but } \\
\text { the } \\
\text { duration } \\
\text { was not } \\
\text { specified }\end{array}$ \\
\hline $\begin{array}{l}\text { Lozano-Balderas } \\
2017 \text { [7] }\end{array}$ & Mexico & Adults & $56(36 / 20)$ & $\begin{array}{l}\text { PC: } 27(20 / 7) \\
\text { DPC: } 29 \\
(16 / 13)\end{array}$ & Laparotomy & Yes & $\begin{array}{l}\text { The wound } \\
\text { was left open, } \\
\text { dressing } \\
\text { technique or } \\
\text { type was not } \\
\text { mentioned }\end{array}$ & 30 days \\
\hline $\begin{array}{l}\text { Siribumrunwong } \\
2018 \text { [24] }\end{array}$ & Thailand & Adults & $\begin{array}{l}607(324 \\
/ 283)\end{array}$ & $\begin{array}{l}\text { PC: } 303 \\
(169 / 134) \\
\text { DPC: } 304 \\
(155 / 149)\end{array}$ & Appendectomy & Yes & $\begin{array}{l}\text { skin was left } \\
\text { open with } \\
\text { saline soaked } \\
\text { gauze } \\
\text { changed } \\
\text { twice daily }\end{array}$ & 4 weeks \\
\hline
\end{tabular}

Table 2

antibiotics prophylaxis used in the included studies.

\begin{tabular}{|ll|}
\hline Study & Antibiotics administered \\
\hline Chatwiriyacharoen 2002 [17] & Gentamicin, metronidazole \\
\hline Duttaroy 2009 [5] & Ceftriaxone, amikacin, metronidazole \\
\hline Khan 2012 [16] & Ampicillin + clavulanic acid, Gentamicin, metronidazole \\
\hline Tsang 1992 [23] & Gentamicin sulphate, metronidazole \\
\hline Lozano-Balderas 2017 [7] & Cephalosporins, metronidazole \\
\hline Pettigrew 1981 [26] & According to surgeons' preferences \\
\hline
\end{tabular}

Figures 


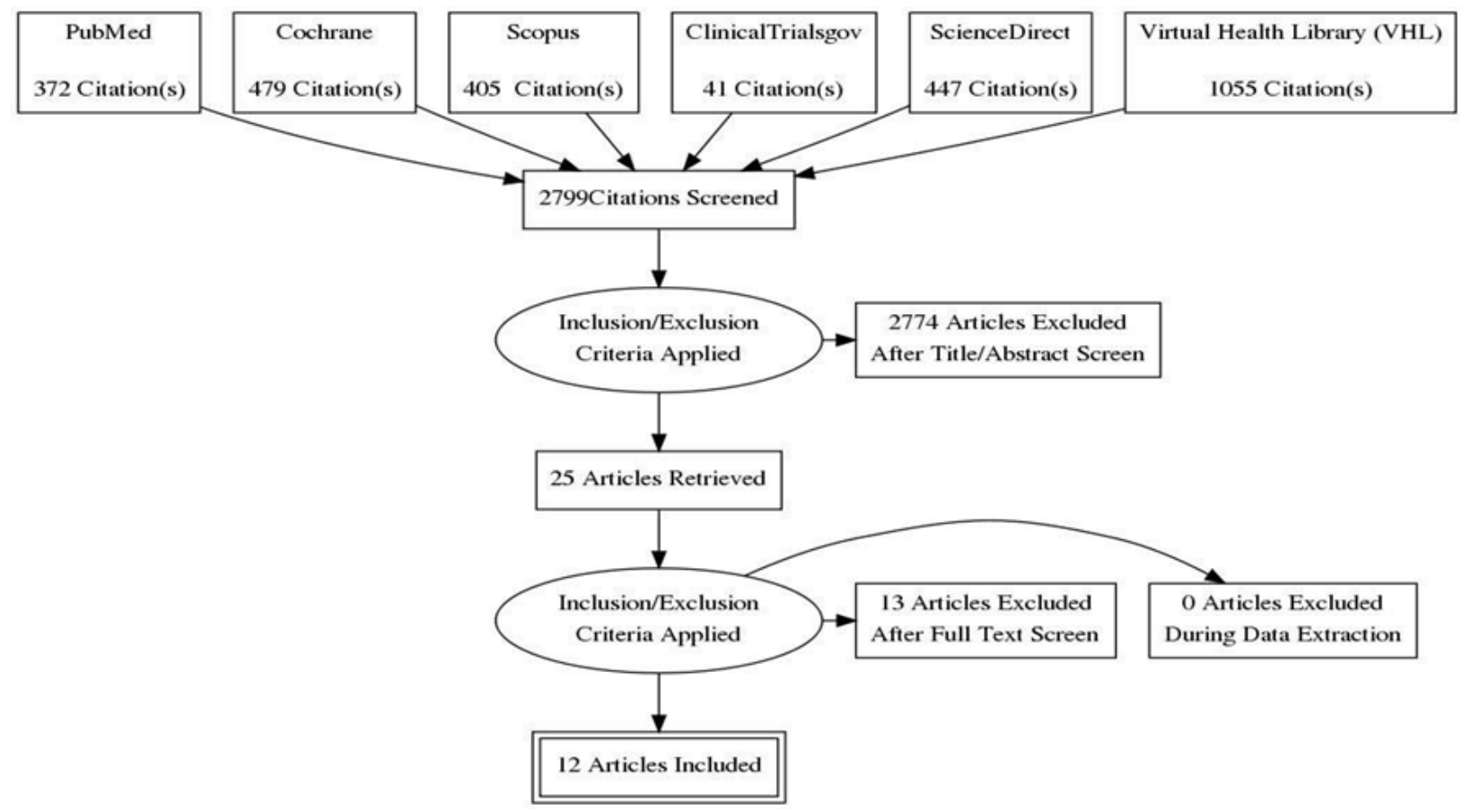

Figure 1

PRISMA diagram of the study selection process.

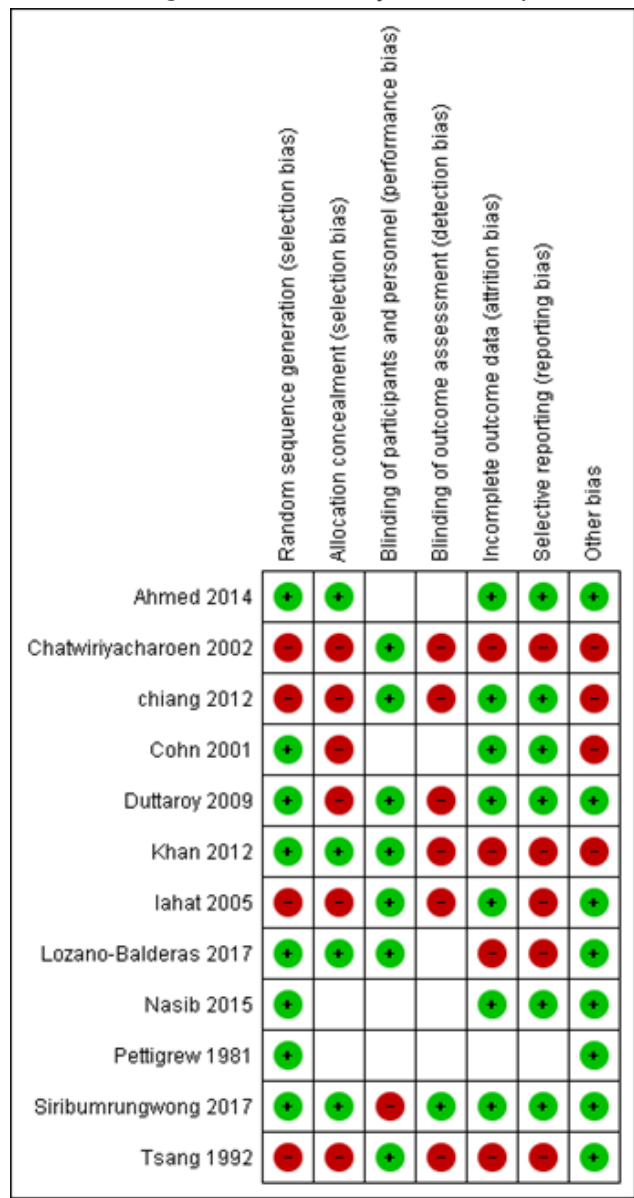

Figure 2

risk of bias assessment summary. 


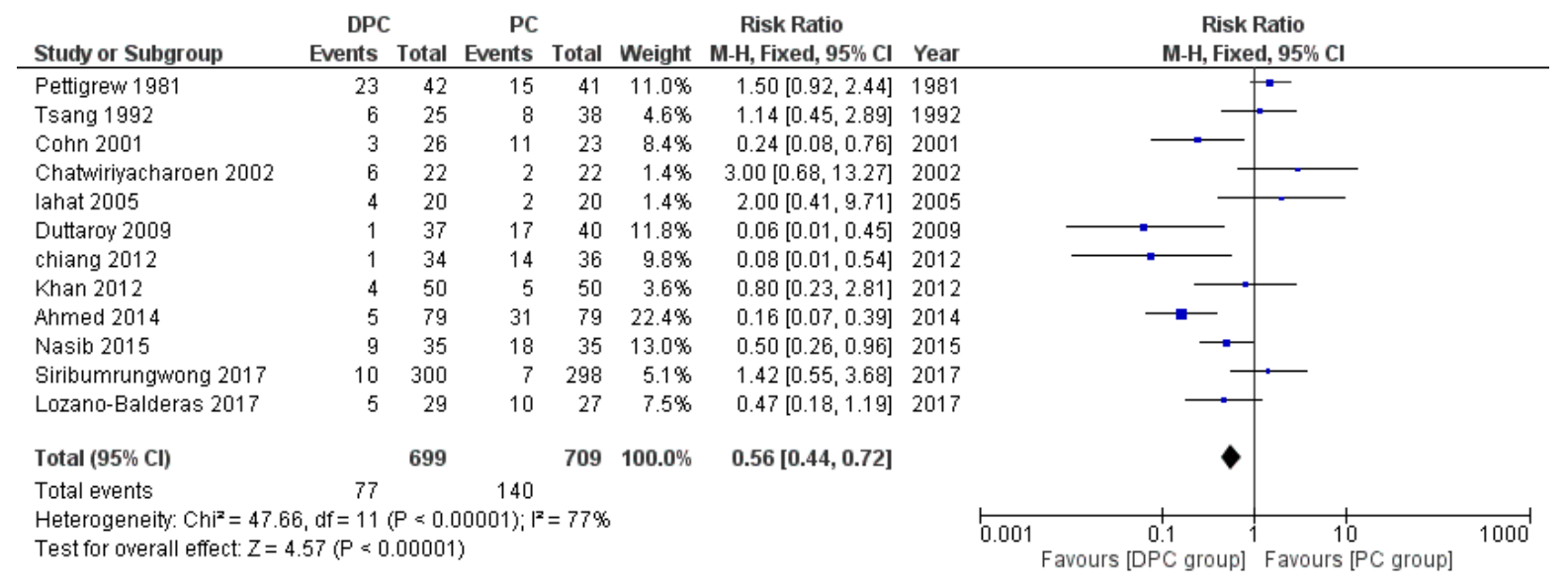

\section{Figure 3}

Comparison of primary skin closure (PC) vs Delayed primary skin closure (DPC) for the risk of SSIs using fixed-effects model. DPC PC

Risk Ratio Events Total Events Total Weight $\mathrm{M}-\mathrm{H}$, Random, 95\% Cl Year

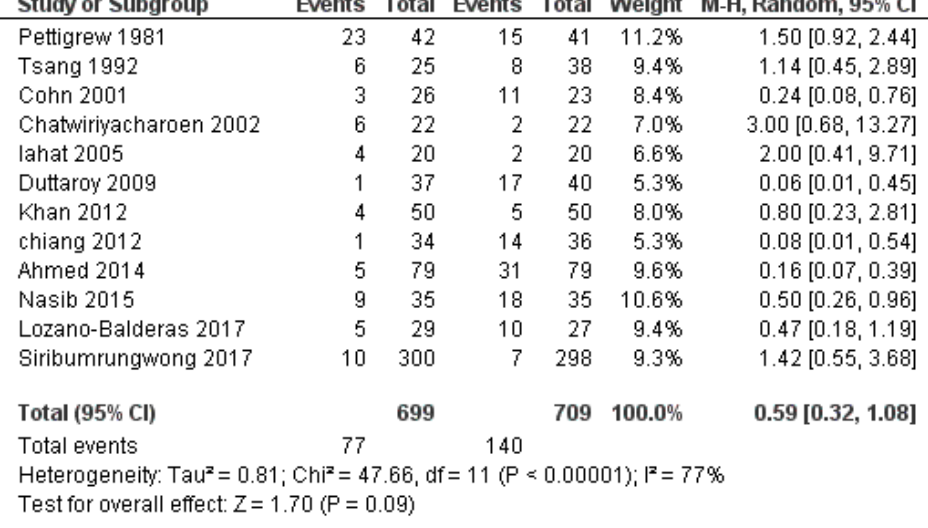

Risk Ratio

M-H, Random, $95 \% \mathrm{Cl}$

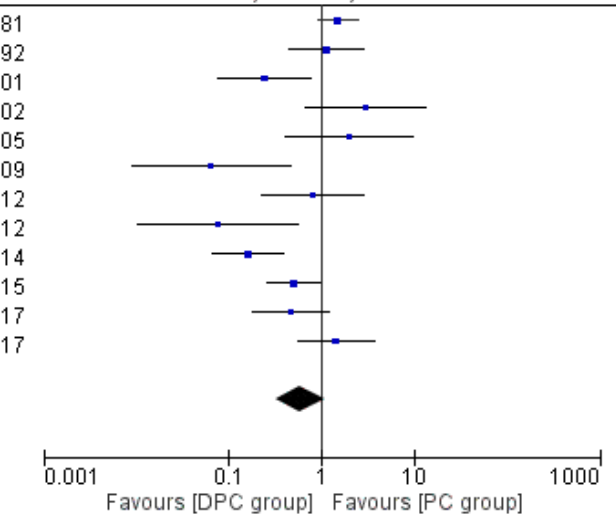

Figure 4

Comparison of primary skin closure (PC) vs Delayed primary skin closure (DPC) for the risk of SSIs using random-effects model.

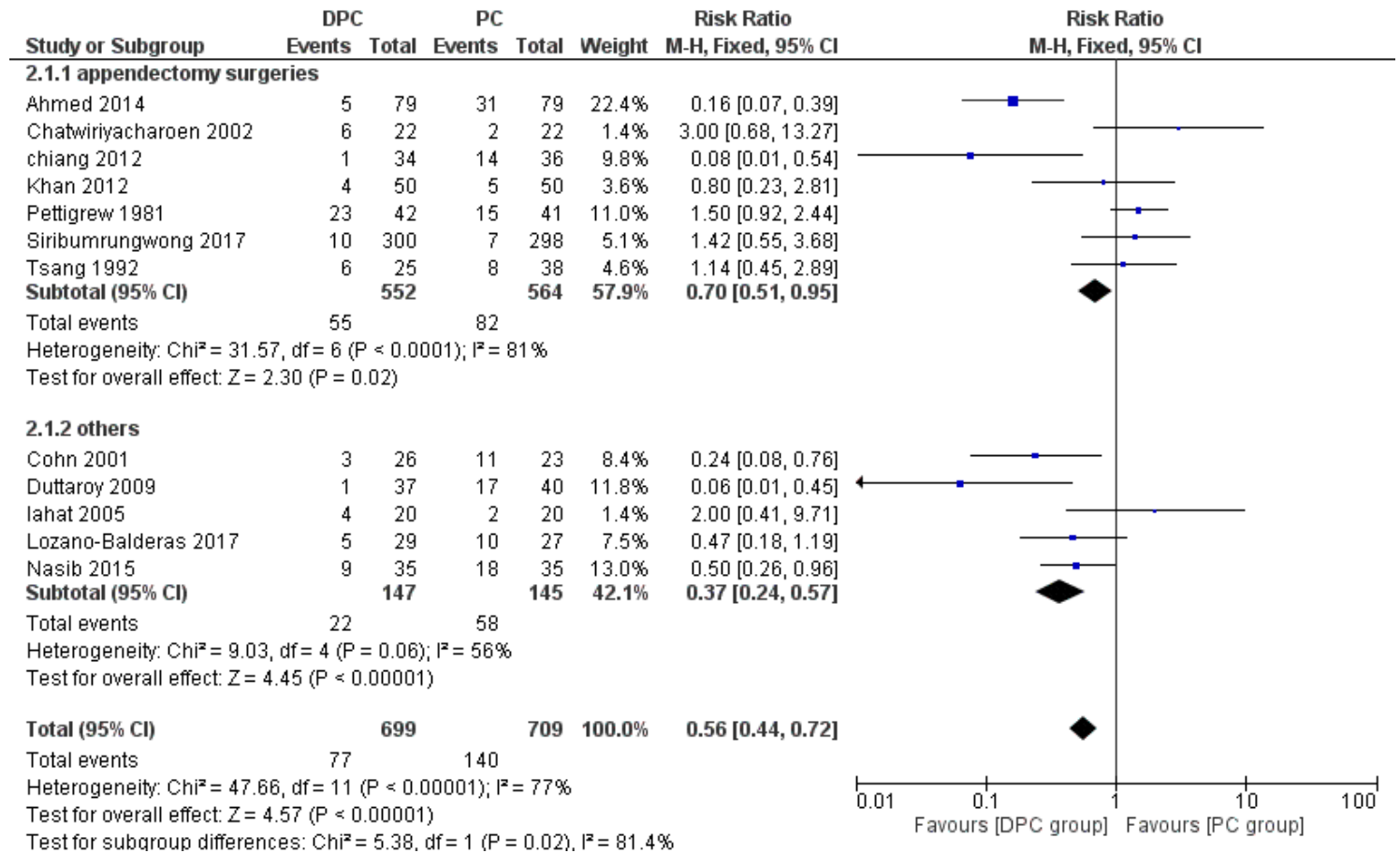

\section{Figure 5}


Sub-group analysis for appendectomy surgeries, comparing the primary skin closure (PC) vs Delayed primary skin closure (DPC) using fixed-effects model.

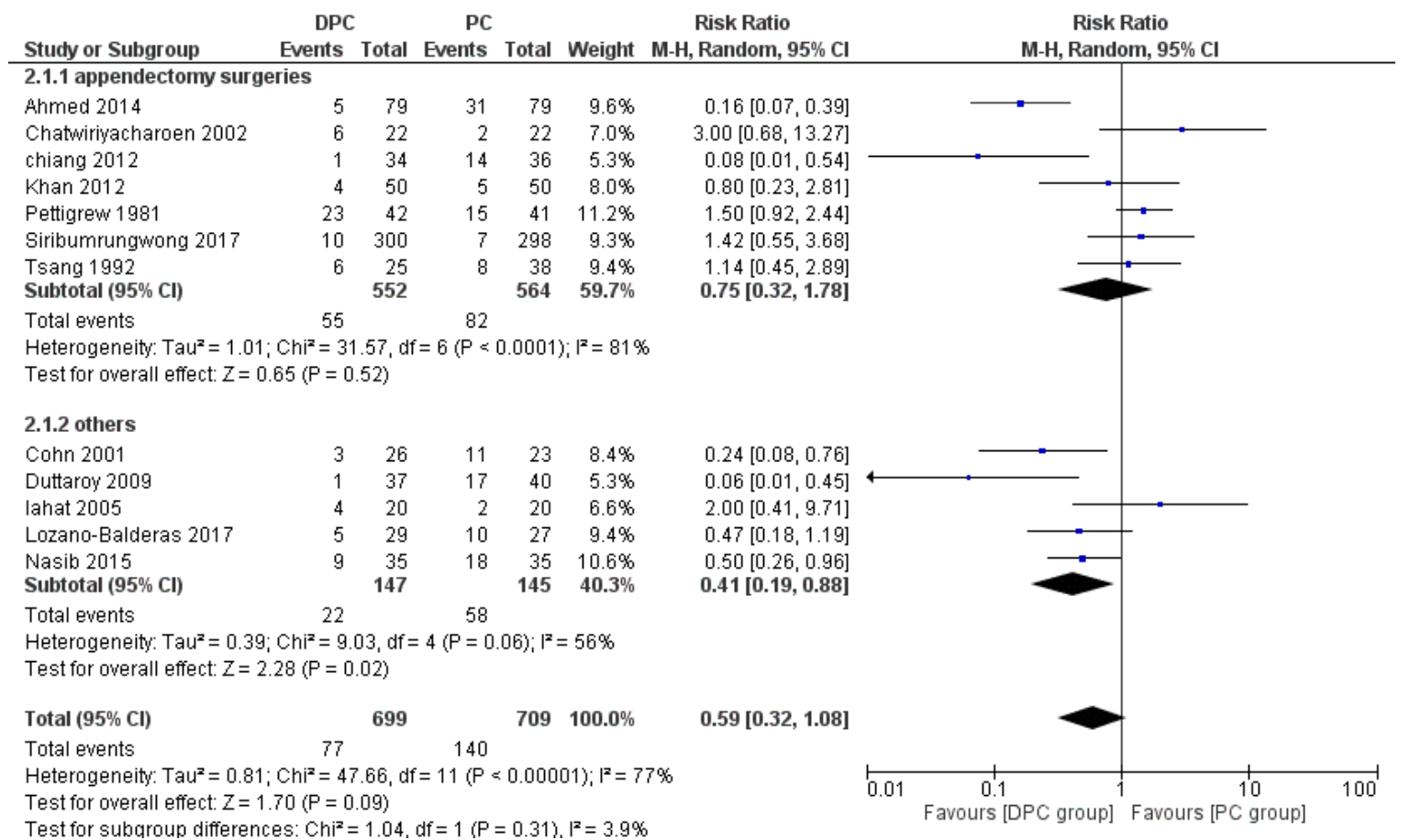

\section{Figure 6}

Sub-group analysis for appendectomy surgeries, comparing the primary skin closure (PC) vs Delayed primary skin closure (DPC) using random-effects model

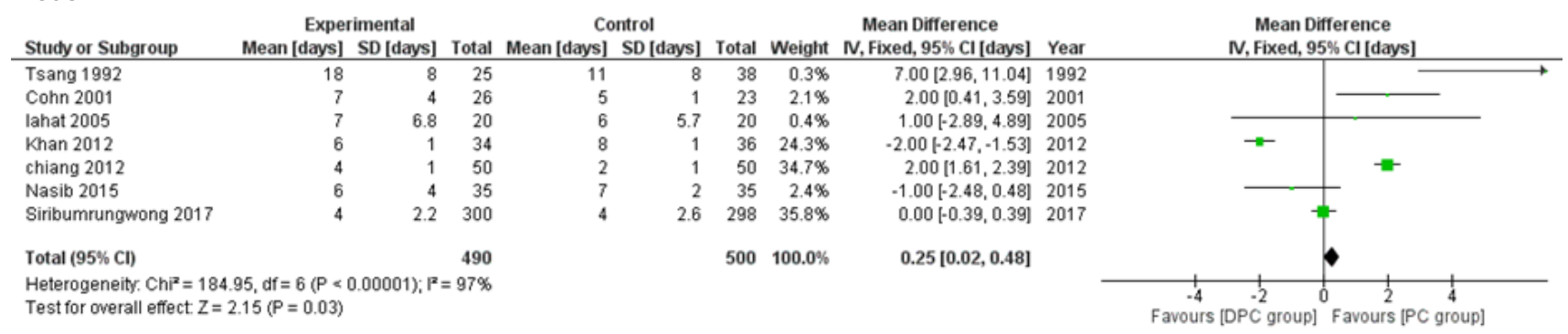

\section{Figure 7}

comparison of primary skin closure (PC) vs Delayed primary skin closure (DPC) for the length of hospital stay using fixed-effects model.

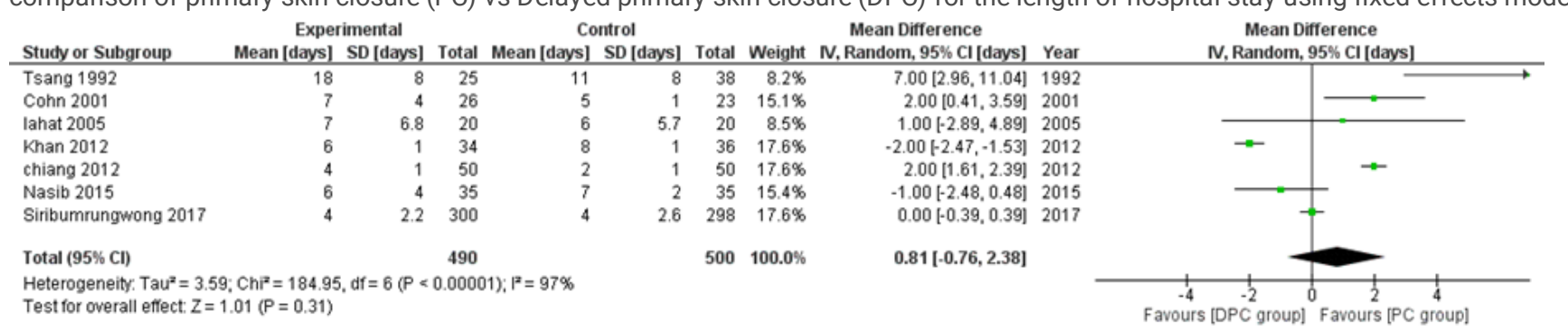

\section{Figure 8}

comparison of primary skin closure (PC) vs Delayed primary skin closure (DPC) for the length of hospital stay using random-effects model. 